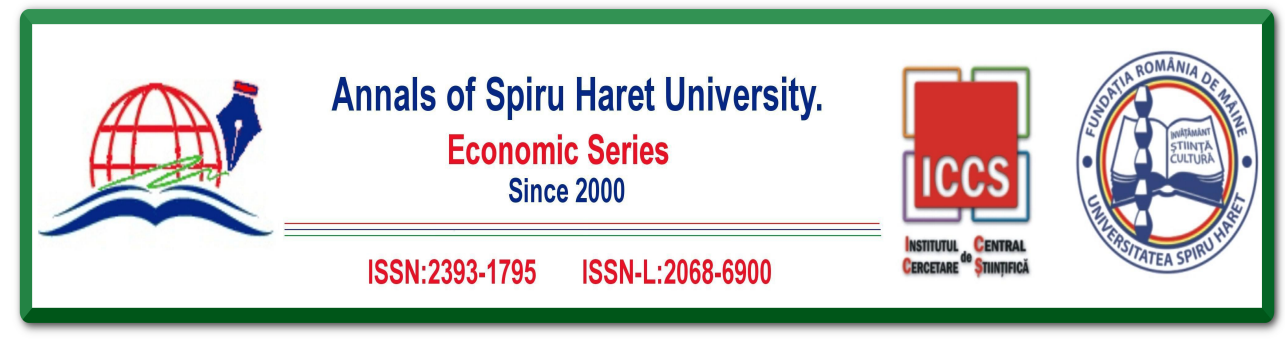

Issue 3/2019

\title{
THE ROLE OF TAX REVENUE AND FOREIGN DIRECT INVESTMENT IN PROMOTING ECONOMIC PROGRESS IN NIGERIA
}

\author{
Fineboy Ikechi JOSEPH ${ }^{1}$, Cordelia Onyinyechi OMODERO², \\ Obioma Manasseh OMEONU ${ }^{3}$ \\ ${ }^{1}$ Clifford University, Owerrinta, Abia State, Tel.: 08036970755, \\ Email: fayooxyz2009@yahoo.com \\ ${ }^{2}$ Clifford University, Owerrinta, Abia State, Tel.: 07034871571, \\ Email: cordeliaomodero@yahoo.com \\ ${ }^{3}$ Clifford University, Owerrinta, Abia State, Tel.: 08036970755
}

How to cite: JOSEPH, F.I., OMODERO, C.O., \& OMEONU, O.M. (2019). "The Role of Tax Revenue and Foreign Direct Investment in Promoting Economic Progress in Nigeria." Annals of Spiru Haret University. Economic Series, 19(3), 33-54, doi: https://doi.org/10.26458/1932

\begin{abstract}
The study examined the impact of tax revenue on economic growth of Nigeria proxied as gross domestic product (GDP) from 2000-2017. The study employed Exploratory and ex-post facto designs and secondary data sourced from Federal Inland Revenue Services (FIRS), UNCTAD, FDI/MNE database, World Bank Report, United Nations Development Programme (UNDP) reports, CBN statistical bulletin. Ordinary Least Squares (OLS) regression technique was adopted to test the hypotheses of the study. The result reveals that tax revenue has significant impact on GDP in Nigeria with R-squared showing that about $87 \%$ variations in GDP can be attributed to tax revenue, while the remaining $23 \%$ variations in GDP are caused by other factors not included in this model. This is further emphasized by the T-statistic p-value of 0.001 which shows that the regression result is statistically significant because it is less than 5\%, level of significance adopted for this study. The result from regression analysis also revealed that there is positive relationship between foreign direct investment and Gross Domestic Product, with a p-value of $+0.000,+0.001<0.05 \%$ significance
\end{abstract}




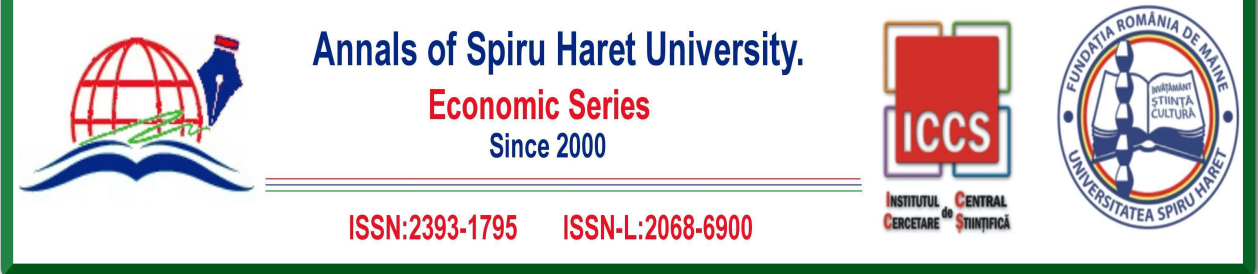

Issue 3/2019

level. The study concluded that tax revenue has a significant impact on GDP in Nigeria. Also there is a positive relationship between FDI and economic growth in Nigeria; therefore the more FDI increases, the more economic growth. The study recommended that functional tax structures that would ensure that tax is collected from all taxable individuals, group of individuals and corporate bodies and remitted accordingly to the government without diversion should be instituted to widen the revenue base of the country. Government should liberalize the Nigerian economy more by removing all barriers to trade such as arbitrary tariffs, import and export duties and other levies to encourage foreign investors.

Keywords: tax revenue, economic growth and GDP, foreign direct investment.

JEL Classification: F21, H20

\section{Introduction}

It is the primary responsibility of government globally to make sure that security, freedom and welfare of its citizenry are catered for. Section 16(1b) of the 2011 Constitution of the Federal Republic of Nigeria precisely has stipulated that it is the responsibility of the government to ensure maximum welfare, freedom and happiness of its citizenry (Federal Government of Nigeria, 2011). Adequate funding is needed for government to effectively carry out its main functions and other supplementary functions. Tax payment of various forms by individuals and corporate bodies is one of the reliable means through which the government realizes the need to play these primary roles. Tax payments has become phenomenally of universal significance owing to how it affects every economy, national differences notwithstanding [Oboh \& Isa, 2012]. For instance, tax revenue is used by the federal government in the provision of infrastructure and other necessary social services such as health facilities and education. The government equally has the primary responsibility of ensuring that the territorial integrity of the nation is defended, ensuring security of lives and property, maintaining good external relations. The government also gets involved in productive activities which the private sector cannot conveniently provide owing to huge capital outlay involved [Sackey et al., 2014].

Ezejelue and Ihendinihu (2006) have defined taxation as the demand made by the government of a country for a compulsory payment of money by the citizens of the country with the objectives of raising revenue to finance government expenditures, satisfy collective wants of the people and regulate economic and social policies. 


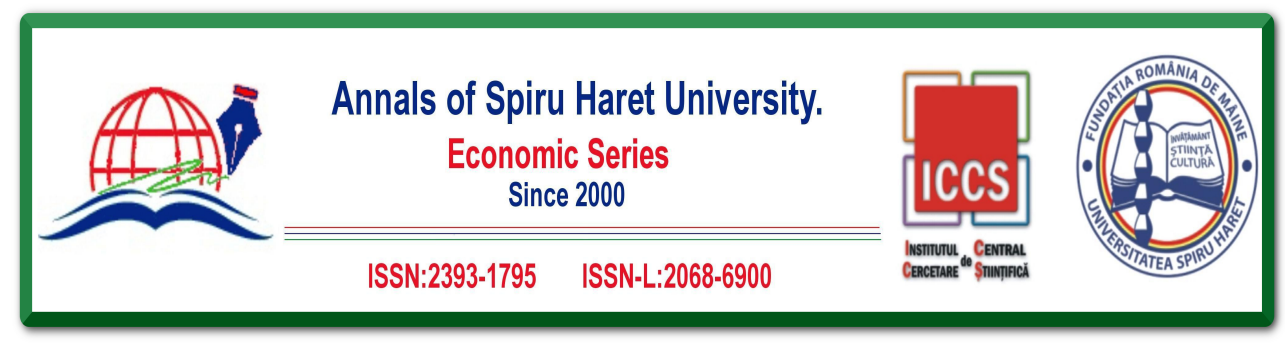

Issue 3/2019

Taxation is a civic responsibility whose assessment is in accordance with all established cannons - the principle of equity, convenience and productivity. The Nigeria tax system features a wide and mixed range of statutes by which various governments in the country seek to change and collect for public expenditure. Of these, the most widely used was based on income and is personal income tax and company's income tax. Taxation is divided into two, namely direct and indirect taxes. Direct tax in Nigeria consists of personal income tax and company's income tax. Indirect taxes are levied against goods and services e.g. stamp duties, entertainment, pool and casino taxes, industrial training funds, custom duties and exercise duties [Joseph et al., 2018]. In a wider sense, there are three (3) main methods open to most developing countries such as ours in financing economic expenditure, namely taxes on other currency receipts, loans and grants. Taxation perhaps is the most important of all these because revenue generated by the system determines expenditure.

To carry out these primary and supplementary responsibilities as expected, the Nigeria government has depended so much on oil revenue which is susceptible to fluctuations owing to market forces and international politics. Recently, the fall in crude price per barrel (below US\$40) almost crippled the government from playing its primary roles; led to recession (among other factors) which the economy is still struggling to pull through fully from. So, overdependence on oil revenue is likened to a house owner who opens his doors midnight amidst insecurity - no doubt, he is venerable to attacks.

It was for this reason that the former Minister of Finance and Coordinating Minister for Economy appealed to governments at various levels to seek alternative revenue sources to ensure sustainability in economic growth and development of Nigeria. Running a democratic government is very expensive especially in Africa because of greed, inflation of contract costs and high rate of corruption generally that results in a situation where public office holders earn bogus salaries and allowances that are not proportionate to available funds. From the foregoing, it has become crystal clear that oil revenue does not sustain developmental goals of the nation, hence the need for alternatives.

Kiabel and Nwokah (2009) opined that the decline in revenue and increased cost of governance has made it necessary for all tiers of Nigerian government to seek alternatives to improve their revenue base. As observed by Kusi (1998), many countries of the world depend mainly on taxation for generating required income to meet their financial needs. Pfister (2009) confirms that tax revenue can be predicted 


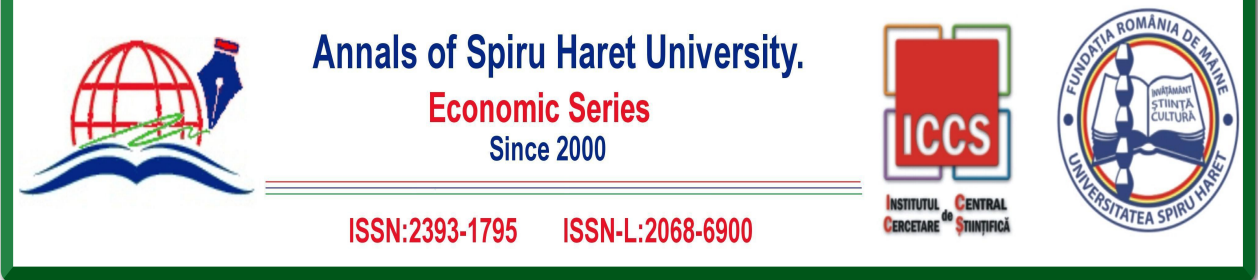

Issue 3/2019

(certainty attribute of taxation). It is stable, therefore provides reliable flow of revenue to finance development goals either in the short and long term.

By ensuring efficiency and effectiveness in the tax system, adequate revenue is generated to finance government expenditure with its attendant positive influence on the needs of the people - standard of living of the citizens.

According to The World Bank Group (2004), "the quality of life of people of a state is the focus of any development objectives. Accessibility to education, improved healthcare delivery, employment opportunities, clean air, safe drinking water, and security of life and property determine the quality of life of a people as well as the standard of living." Taxes can be used as an instrument towards the achievement of micro and macroeconomics goals particularly in developing nations such as Nigeria. As observed by Musgrave and Musgrave (2004), the dwindling level of tax revenue generation in developing countries makes it difficult to apply tax as a veritable instrument of fiscal policy for the achievement of economic development. Tax revenue generated from Company Income Tax, Value Added Tax, and Personal Income Tax has greatly impacted positively on economic development of countries such as the USA, Canada and the United Kingdom to mention but a few [Oluba, 2008].

"In Africa, natural resources such as income from production sharing, royalties, and corporate income tax on oil and mining companies yield the significant portion of tax revenue" [Pfister, 2009] in Chukwunwike and Ofoegbu, 2016. Chukwunwike and Ofoegbu (2016) observed that tax sources are the fundamental and most reliable sources of government revenue. This is because of their certainty and flexibility characteristics. Certainty characteristic implies that collection of taxes from taxpayers is assured, all other things being equal. The state of the economy does not affect tax. Take for instance, whether the economy is declining, stagnant or growing. Its flexible nature makes it possible for the government to amend the tax system to be suitable to its needed purpose. There are many research works related to tax revenue and economic development of Nigeria with conflicting results. In some of those research works, economic development and economic growth are used interchangeably. This research work adopted economic growth applying Gross Domestic Product (GDP) as an indicator for measuring economic growth [Worlu, \& Emeka, 2012]. The amount of tax revenue can influence budget figures. The more tax revenue, the more budget figures increase. The consequence would be increase in expenditure of government in the provision of welfare services and infrastructural facilities which would enhance the standard of living of the citizenry. There may be an increase in GDP 36 


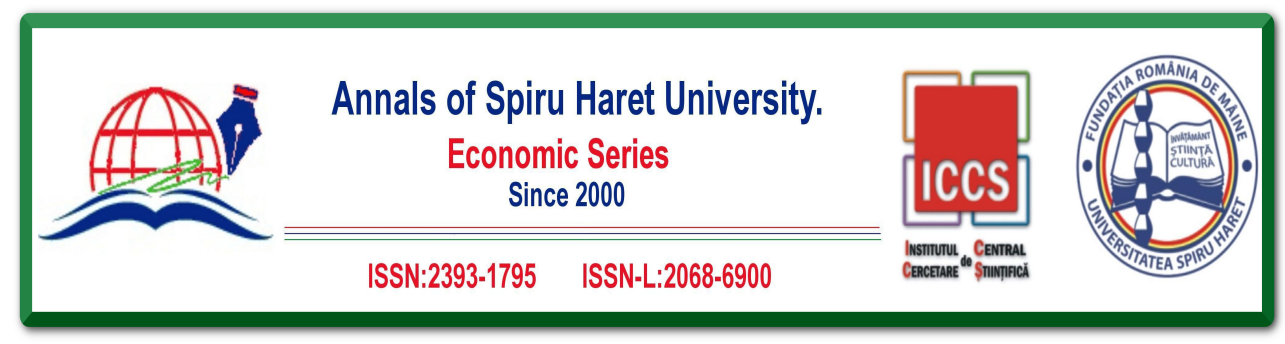

Issue 3/2019

without any actual improvements in the standard of living of the people, and that culminates in economic growth without development [Chukwunwike, \& Ofoegbu, 2016]. The objectives of this study include testing the impact of tax revenue (not segregated into VAT, PIT and CIT) on economic growth in Nigeria proxied as Gross Domestic Product (GDP) and the relationship between FDI and economic growth in Nigeria for the period covered by the study.

The following are the objectives, research questions and hypotheses for the study.

\section{Objectives of the Study}

a. To determine the impact of total tax revenue figures on economic growth in Nigeria.

b. To ascertain the relationship between FDI and economic growth in Nigeria.

\section{Research Questions}

a. Does a total tax revenue figure have any significant impact on economic growth in Nigeria?

b. What is the relationship between FDI and economic growth in Nigeria?

\section{Hypotheses}

a. $\mathbf{H O}_{1}$ : Tax revenue has no significant impact on GDP in Nigeria.

b. $\mathbf{H O}_{2}$ : There is no positive relationship between tax revenue and FDI in Nigeria.

This study, as way of filling a gap in related studies, statistically investigates the relationship between aggregate tax revenue per annum and government annual aggregate expenditure in Nigeria. It critically examines the impact of aggregate tax revenue on Gross Domestic Product (GDP) in Nigeria.

Division of this paper into five parts as shown below helps to achieve its objectives as follows. Introduction is part one. It captures the background of the study, key issues relating to importance of tax revenue in adequate financing of the developing countries, especially in Nigeria. It looks into the reasons tax revenue has not been used adequately in growing the economy when compared with developed nations of Europe and the USA. The objectives, hypotheses and gaps filled are captured in this part. Part two deals with review of related literature and some theories underlying taxation and how related they are with economic growth. Part three captures research methodology. The focus of part four is on data presentation, analysis and discussion of findings related to this study. Part five summarises the 


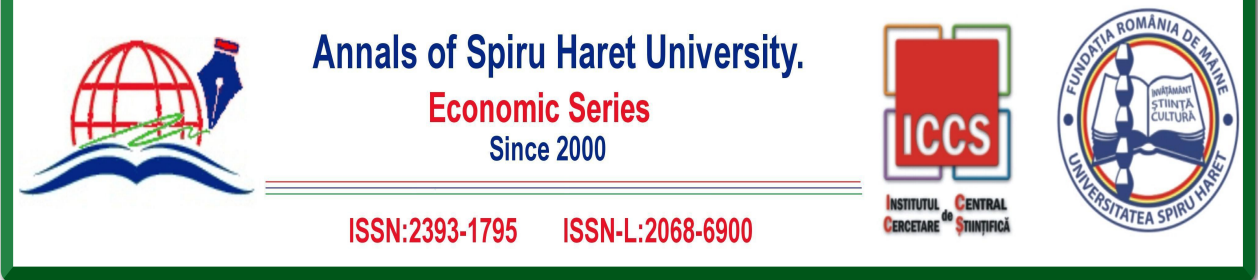

Issue 3/2019

paper, draws conclusion and makes recommendations based on results of the tests conducted.

\section{Review of Related Literature}

\subsection{The Concept of Taxation and the Scope}

Ezejelue and Ihendinihu (2006) defined taxation as the demand made by the government of a country for a compulsory payment of money by the citizens of the country with the objectives of raising revenue to finance government expenditures, satisfy collective wants of the people and regulate economic and social policies. From the foregoing, it can be deduced that what makes tax payment compulsory by the citizens, groups and corporate bodies is because it has legal backings. It is a veritable instrument for the financing of government developmental objectives and because of its certainty and reliability objectives; it generates public funds for financing of government projects.

Similarly, Ogundele (1999) describes taxation as "the transfer of real economic resources from private sector to the public sector to finance public sector activities." It may be concluded from the foregoing that taxation is "the transfer of financial resources from private economic agents like households and corporate bodies, to the public sector to finance the development of the society" [Ojong et al., 2017].

Based on the definition of taxation, Nzotta (2007) in [Ojong et al., 2017] recognized four key issues which must be understood for taxation to play its functions in any society. First, a tax is a compulsory contribution made by the citizens to the government and this contribution is for general common use. Second, a tax imposes a general obligation on the tax payer. Third, there is a presumption that the contribution to the public revenue made by the tax payer may not be equivalent to the benefits received. Finally, a tax is not imposed on a citizen by the government because it has rendered specific services to him or his family.

Individuals, group of individuals and corporate entities are expected to make this payment based on their income, profit or wealth of group person. A well-designed tax system that functions effectively and efficiently can help developing countries' governments prioritize their spending, put together stable institutions, and advance democratic accountability [Brautigam, 2008]. As observed by Ezejelue and Ihendinihu (2006), the primary purposes of tax revenue include raising revenue to finance government expenditures, satisfy collective wants of the people and regulate economic and social policies. Taxation can aide in the redistribution of common 38 


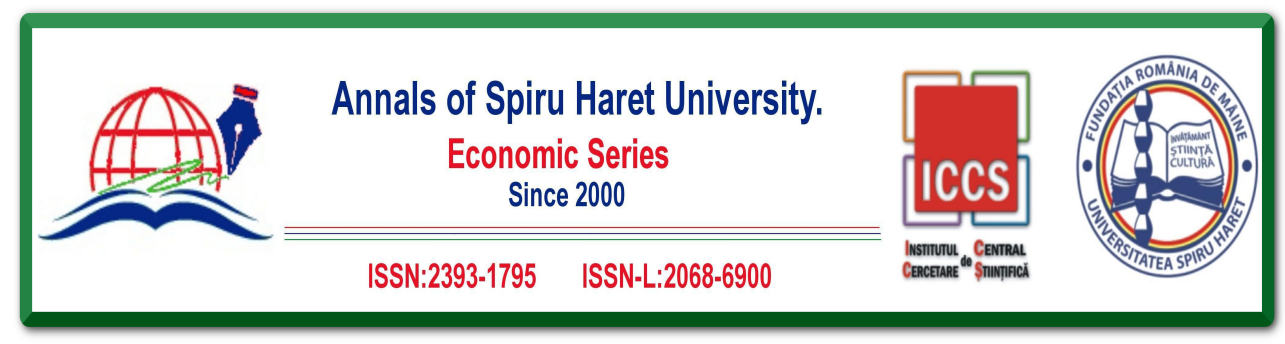

Issue 3/2019

wealth to ensure social justice [Ola, 2001]. Therefore, taxes can be used as an instrument for achieving both micro and macroeconomic objectives especially in developing countries such as Nigeria [Chukwunwike, \& Ofoegbu, 2016]. Nevertheless, Musgrave and Musgrave (2004) noted that the declining level of tax revenue generation in the developing countries makes it difficult to use tax as an instrument of fiscal policy for the achievement of economic development. Canada, the United States, Netherland, and the United Kingdom have to a large extent influenced their economic development through tax revenue generated from Company Income Tax, Value Added Tax, and Personal Income Tax, and have attained great heights through tax revenue [Oluba, 2008].

\subsection{Principles of Taxation}

Anyanfo (1996) opines that the principles of taxation describe the suitable criteria to be adopted in the development and appraisal of the tax structure. Such principles are derivations from welfare economists and their applications as well. To entrench the wider objectives of social justice, the tax system of a country should revolve on sound principles. Based on the study conducted by Jhingan (2004), Bhartia (2009) and Osiegbu et al. (2010), the following principles of taxation were listed as follows: equity, certainty, convenience, economy, simplicity, productivity, flexibility and diversity. These principles are expected to make tax payment interesting to the taxpayer as well as boost their confidence.

Equity principle: denotes that every taxpayer should pay tax proportional to the taxpayer's income. Jhingan (2004) stated that the wealthy should pay more and at a higher rate than the other individual whose income is less. Anyanfo (1996) in Ogbonna and Appah (2012) state that only when a tax is based on the taxpayer's capacity to pay that it can be regarded as equitable or just. At times, this principle is construed to mean proportional taxation.

Certainty principle: As noted by Bhartia (2009), this principle of taxation states that a tax which each individual is supposed to pay ought to be definite/certain, not arbitrary. The certainty should manifest in relation to the time of payment, the mode of payment, the amount to be paid, things that must be clear and plain to the taxpayer and every other person.

Convenience principle: This states that the time and manner for tax remittance should be convenient to the taxpayer. As put forward by Anyanfo (1996), this principle of taxation provides the justification for Pay-As-You-Earn (PAYE). 


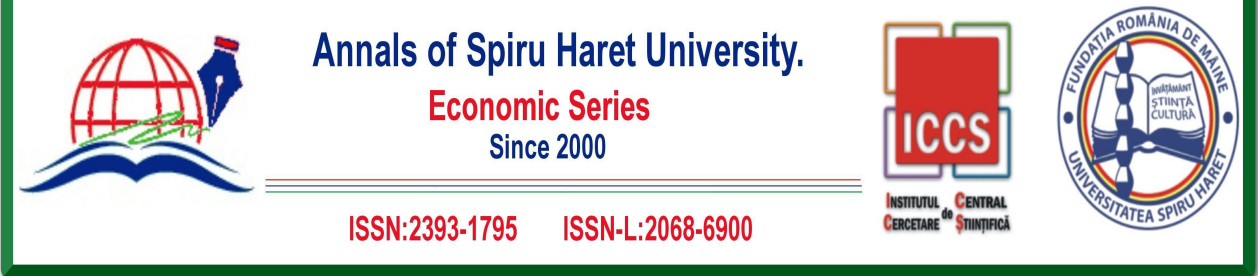

\section{Issue 3/2019}

Economy principle: This emphasizes that every tax should be economical for the state to collect and the taxpayer to pay [Appah, 2004; Jhingan, 2004; Bhartia, 2009] in Ogbonna and Appah (2012). Anyanfo (1996) stressed that this principle entails that taxes should not be imposed where it is ascertained that their collection cost surpasses the benefits.

Productivity principle: This principle denotes that a tax, as it is expected, brings in large revenue adequate enough for the government to carry out its financial and developmental goals. It is the main reason governments in all parts of the world continuously take up tax reforms [Ogbonna, \& Appah, 2012].

Simplicity principle: As regards this principle, tax should be plain, simple and comprehensible to common taxpayer. Anyanfo (1996) argued that there should be no hidden agenda in the tax law. Transparency ought to be the watch word of an efficient tax system.

Flexibility principle: implies that there should be no rigidity in taxation. That is to say that there ought to be variety of taxes. Diversity Principle of taxation states that there should be variety of taxes. Bhartia (2009) argued that it is dicey for state to rely on too few sources of public revenue.

\subsection{Taxation Payable in Nigeria}

In Nigeria, taxes payable by taxpayers are categorised as either direct or indirect tax. In Nigeria, the government can place emphasis on any one of the tax forms depending on the objective it wants to attain [Ofoegbu et al., 2016]. Though there are other forms of taxes, emphasis is placed more on the aforementioned forms of taxes - direct and indirect. The direct tax describes a levy remitted on personal income, corporate income or property. Instances are Company Income Tax, Personal Income Tax, Petroleum Profit Tax, and Capital Gains Tax. Indirect tax is an imposition on the price of goods and services. Indirect tax is paid on the consumption of goods and services associated with import duties or tariffs, export duties, value added tax and excise duties. There are different legislations that allow the government tax its citizens and to increase the tax revenue of the country; those are the Personal Income Tax Amendment Act 2011, the Companies Income Tax Amendment Act 2007, the Petroleum Profit Tax Amendment Act 2004, the Capital Gains Tax Amendment Act 2004, the Value Added Tax Amendment Act 2007 and the Education Tax Amendment Act 2004. Federal Inland Revenue Services is in charge of the administration and collection of these taxes (except customs/excise duties). 


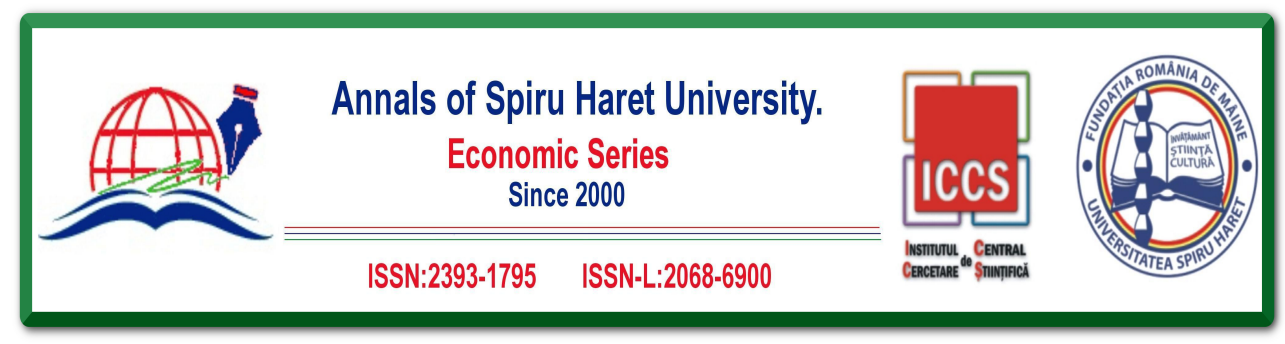

Issue 3/2019

Nigeria has recorded an increase in tax revenue above the target every year. The Federal Inland Revenue Service (FIRS) reported taxation increased from N2.83 trillion to N4.71 trillion between 2010 and 2014. These figures do not include those taxes collected by tax authorities in the State Board the Local Government Revenue Committee (LGRC) [Ofoegbu et al., 2016].

2.4. The Nigerian Economy and Its Nature: The three sectors of the Nigerian economy are primary (agriculture/natural resources), secondary (processing and manufacturing), and tertiary (services) sectors. The economy is dominated by agriculture and petroleum sectors. In the 1960s and early 1970s, the primary revenue earner was agriculture (largest revenue earner then) and from the late 1970s to date, it turned to be the oil sector. According to Apata et al (2011), agriculture was the heart of economic activities then and was followed by manufacturing and mining activities at very low levels of development.

Nigeria, from the early 1970s, suddenly had an enormous increase in revenue from the sales of crude oil. Ezirim et al. (2010) noted that this sudden wealth from crude oil was invested in socio-economic infrastructures across the country particularly in the urban cities and this led to a high growth rate of the country's service sector. The investment in the socio-economic infrastructure led to a movement of young men and women from the hinterland to the urban cities thereby escalating the oil-driven urban economy. This sweeping movement crumbled the agricultural sector as oil became Nigeria's key source of revenue. Agriculture and agricultural business activities was left in the hands of the aged in remote villages. The migration of the young men and women did not go without its social and environmental problems like congestion, pollution, unemployment and criminal activities.

Both the prolonged military rule and the civilian government in Nigeria (democratic government) for over half a century have created more social economic stagnation. These governments have continued to mismanage and misappropriate the common wealth of Nigeria resulting in low standard of living of the people, poverty, poor infrastructural facilities and poor ranking of Nigeria in Human Development Index (HDI). Though there are claims that some economic progress have been made by the present and previous civilian governments in terms of increase in Gross Domestic Product (GDP), poverty rate is high and has even increased, unemployment is worsening, poor infrastructure and ethno-religious crisis have been 

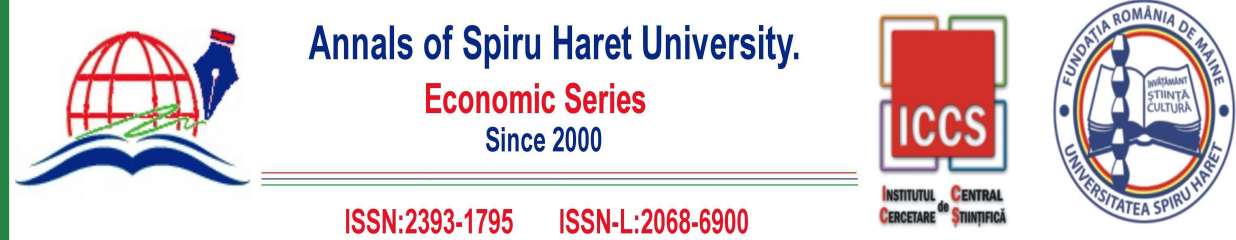

Issue 3/2019

the order of the day. At this juncture, one begins to wonder how economic prosperity of a nation is measured taking a close look at these negative developments.

Presently, Nigeria is working towards expanding her financial, telecommunications service, entertainment and technology sectors that are all contributing to the growth of her Gross Domestic Product (GDP). Some challenges to the country's rapid economic development are the inadequate power supply, lack of key infrastructure, and the general fall in the price of oil that has given rise to the severe reduction in the country's total revenue [Ofoegbu et al., 2016].

\subsection{Economic Development and Growth Described}

A policy intervention effort targeted at the economic and social well-being of people is termed economic development (Salmon Valley Business Innovation Centre, 2014). It concerns itself with improvement in the quality of life of people, creation of new goods and services using modern technology, lessening of risk and bringing to bare dynamics of innovation and entrepreneurship [Hadjimichael et al., 2014] in [Ofoegbu et al., 2016]. The objective of economic development is to make the environment favourable for local communities and regions to develop new ways of production of goods in such quantities that may lead to exportation to other countries. Availability of financial resources from exportation leads to more investment in infrastructure for the benefit of the society and improvement in living conditions of the people, in education, transportation networks, health conditions, water supply, sewage and sanitation conditions (SVBIC, 2014) in [Ofoegbu et al., 2016]. The changes create the conditions for long-run economic growth by positioning the economy on a higher growth trajectory [Hadjimichael et al., 2014] in [Ofoegbu et al., 2016]. Economic development is different from economic growth. Economic growth specifically means an increase in the value of goods and services produced by a country over a period. Economists use an increase in nation's GDP to measure it. Therefore, it is possible to have economic growth without economic development in the short or even medium term [Hadjimichael et al., 2014]. On the other hand, there could be an increase in GDP without any increase in standard of living of people in a state. Environmental conditions that would enhance economic growth must be created through an investment of the national wealth in infrastructural development for successive improvement in the standard of life of the population of a country [Wilkins, \& Zarawski, 2014] in [Ofoegbu et al., 2016]. Authors use economic growth and development interchangeably and also use GDP as measurement indicator for 42 


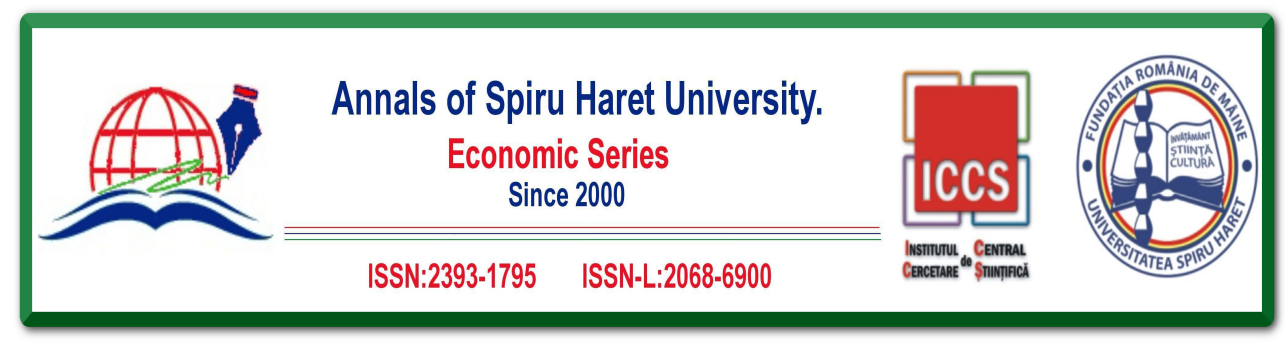

Issue 3/2019

both. On the other hand, given that the two are different, any effort to use GDP as a measure for the two gives inaccurate outcome on economic development. Robert et al. (2009) placed emphasis on the need for an innovative measure of progress in the wellbeing of people. He argues that GDP is not a good measure because economic growth is the same with well-being.

Furthermore, according to the United Nations report on Human Development Index (HDI) "development is much more than just the expansion of income and wealth. It connotes a process of enlarging people's choices" [UNDP, 1990]. It is a shift to a more holistic perception of development that had earlier focused more on per capita income. United Nation's Human Development released Human Development Index (HDI) first as part of her 1990 Report. The United Nations came up with Human Development Index (HDI) as a parameter for ranking countries' levels of social and economic development based on the following namely Health Index, Education Index, and Standard of Living Index. The health index is a representation of life expectancy (expected numbers of years) of a particular region or country under study. Human Index (HI) in a correct manner explains the degree to which life expectancy of the people in the area or country under study is above the minimum (least) life expectancy. United Nations (UN) report has it that the minimum and maximum life expectancy in the world is put at 25 years and 85 years correspondingly [UNDP, 2014] in [Ofoegbu et al., 2016]. The Education Index (EI) shows the literacy rate and enrolment rate of people, in a particular region or country under study. The Literacy rate indicates the percentage of people of 16 years of age and above who are literates [UNDP, 2014] [Ofoegbu et al., 2016]. These are people who must be able to write, read and understand a simple statement regarding their daily life activities. Enrolment rate is the percentage of children who are within school-going age bracket, be it primary, secondary and tertiary. The living standard index indicates the per capita income of a region or country stated in US\$ at Purchasing Power Parity (PPP) rate. It shows the income of a country, the exchange rate between the country's currency and US\$, and the price level index of the country in comparison to the US price level. Nigeria's HDI value for 2014 is 0.504 , which is in the low human development category ranking the country at 152 out of 187 countries and territories. The Nigeria's HDI value increased from 0.466 to 0.504 , between 2005 and 2014, an average annual growth of about 0.81 percent or an increase of 8.1 percent [UNDP, 2014] in [Ofoegbu et al., 2016]. 


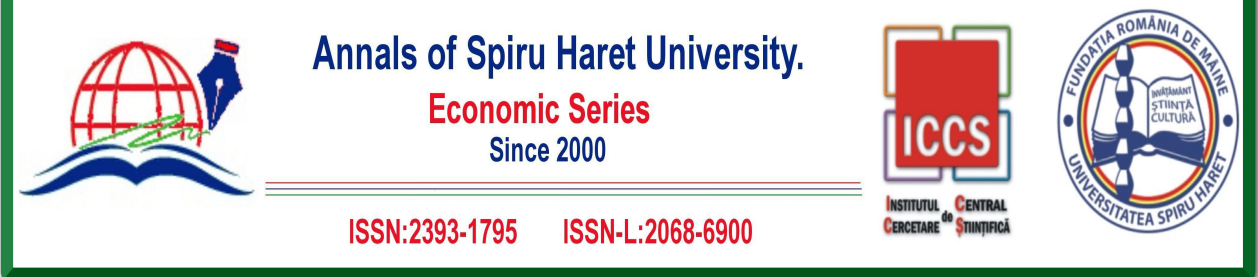

Issue 3/2019

2.6. Tax Revenue, Foreign Direct Investment, Economic Growth and Development of the Nigerian Economy

Worlu and Emeka (2012), in a study on the impact of Tax Revenue on the economic growth of Nigeria between 1980 and 2007 regarding its effect on infrastructural development, opined that tax revenue has direct and indirect relationships with the infrastructural development and the gross domestic product respectively (GDP). The study argued that the means through which tax revenue affects economic growth in Nigeria are infrastructural development, Foreign Direct Investment (FDI) and Gross Domestic Product (GDP). They stressed that availability of infrastructure stirs up an investment that in turn brings about economic growth. It can be inferred from the foregoing that timely and adequate provision of critical infrastructure send positive signal to potential foreign investors to invest their wealth and boost the confidence of existing investors to retain their wealth in the country. By this mechanism, FDI is boosted resulting in industrial growth, creation of more employment opportunities, and increase in per capita income, increased tax revenue through VAT, PIT and CIT et cetera. All these would lead to economic development.

\subsubsection{Theoretical Framework}

This study reviewed four taxation theories, namely benefit received theory, cost of service theory, faculty theory and socio-political theories of taxation. Bhartia (2009) noted that a taxation theory may be based on a relationship between tax liability and state activities. This reasoning gives justification for the imposition of taxes for financing state activities/projects and also providing a basis for apportioning the tax burden between members of the society. This way of thinking yields the benefit received theory and cost of service theory. Also available is the faculty theory of taxation.

Benefit Received Theory: This theory proceeds on the assumption that there is basically an exchange relationship between taxpayers and the state. The state provides certain goods and services to the members of the society and in turn they contribute to the cost of these supplies in proportion to the benefits received [Bhartia, 2009] in [Ogbanna, \& Ebimobowei, 2012]. Anyanfo (1996) in [Ogbonna, \& Ebinmobowei, 2012] argues that taxes should be allocated on the basis of benefits received from government expenditure.

Cost of Service Theory: This theory is similar to the benefits received theory. It emphasizes the semi-commercial relationship between the state and the citizens to a 44 


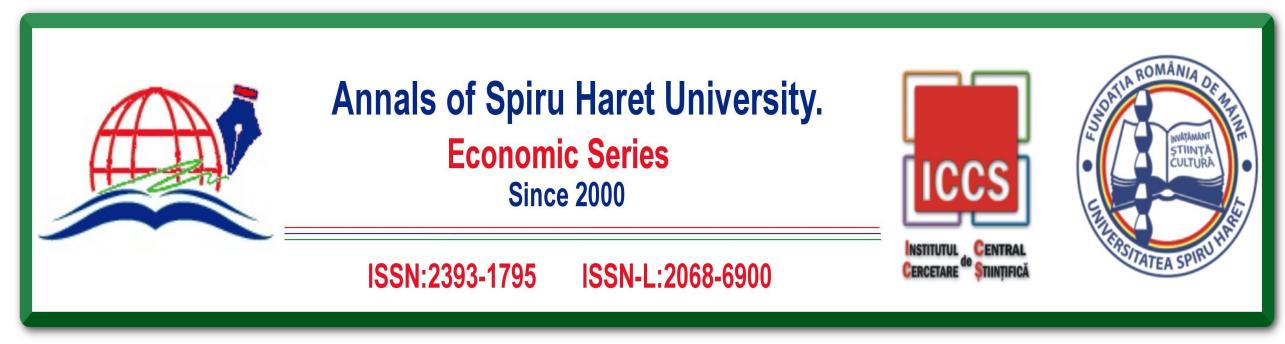

Issue 3/2019

greater extent. In this theory, the state is being asked to give up basic protective and welfare functions. It is to scrupulously recover the cost of the services and therefore this theory implies a balanced budget policy [Ogbonna, \& Ebimobowei, 2012].

Faculty Theory: Anyanfo (1996) noted that this theory denotes that one should be taxed based on ones capacity/ability to pay. This theory is an attempt to maximize an explicit value judgment about the distributive effects of taxes. Bhartia (2009) argues that a citizen is to pay taxes just because he can, and his relative share in the total tax burden is to be determined by his relative paying capacity. This buttresses the equity principle of taxation.

The Socio-Political Theory: This theory of taxation states that social and political objectives should be the key factors in selecting taxes. The theory believes that a tax system should not be planned in such a way that individuals are served, but should be used to treat the ills of society as a whole [Bhartia, 2009]. Since economic objectives of a government have strong relationship with political development in a country, this study therefore settles with this theory.

\subsubsection{Review of Empirical Studies}

Worlu and Emeka (2012) studied the impact of tax revenue on the economic growth of Nigeria for the period 1980-2007 looking at its effect on infrastructural development. The study discovered that tax revenue has both direct and indirect correlation with the infrastructural development and the gross domestic product respectively (GDP). The study argued that the means through which tax revenue influences economic growth in Nigeria are infrastructural development, Foreign Direct Investment and Gross Domestic Product (GDP). It stressed that availability of infrastructure speeds up investments that in turn brings about economic growth.

Bukie and Adejumo (2013) as quoted in Ofoegbu, Akwu and Oliver (2016) examined the effect of tax revenue on economic growth of Nigeria within the period 1970 to 2011, regressing indicators of economic growth (domestic investment, labour force and foreign direct investment) on tax revenue. The result shows that the indicators all have a positive and significant relationship with economic growth in Nigeria.

Onaolapo, Fasina, and Adegbite (2013) studied empirically the effect of petroleum profit tax (PPT) on Nigeria economy. Secondary data were collected from Central Bank of Nigeria statistical bulletin over the 1970 to 2010 period. Multiple regressions were used to run analysis on data on such variables as Gross 

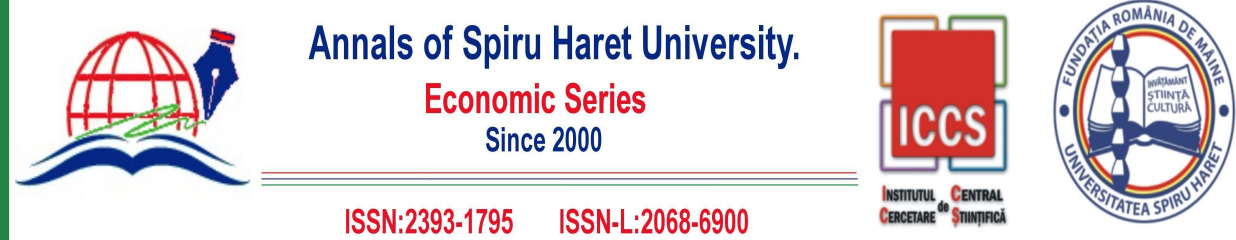

Issue 3/2019

Domestic Product (GDP), petroleum profit tax, inflation, and exchange rate. There were all found to have considerable effects on the Economics Growth.

Ihenyen and Mieseigha (2014) examined taxation as an instrument of economic growth in Nigeria. Using annual time series data sourced from the Central Bank of Nigeria (CBN) Statistical Bulletin during the period 1980 through 2013, data of Corporate Income Tax (CIT), Value Added Tax (VAT) and Economic Growth (GDP) was estimated using the Ordinary Least Square (OLS) technique. The empirical result suggests that the hypothesized link among corporate income tax, value added tax and economic growth indeed exist in the Nigerian context. Therefore the result provides enticing evidence that taxation is an instrument of economic growth in Nigeria. This conclusion points to the need for additional measures by government in ensuring that taxpayers do not indulge in tax avoidance and evasion so that income can be properly redistributed in the economy.

Omodero (2019) investigated the relative impact of agriculture, oil and non-oil tax revenue on Nigeria's economic expansion using data that covered a period from 1981-2017. The study found evidence that agriculture and non-oil tax revenue had a strong and significant positive impact on economic growth of Nigeria while the dwindling oil revenue had significant negative influence on economic expansion of the country.

\section{Research Methodology}

\subsection{Research Design}

Exploratory and ex-post facto designs were adopted in this study. The exploratory design helped the researcher to gather related materials from various sources such as text books, journal articles. The ex-post facto design was adopted on the grounds that it does not provide the study the chance to influence or control the variables majorly because they have already taken place and cannot be manipulated.

\subsection{Method and Sources of Data}

The study primarily used secondary source of data. Time series data were collected through desk survey method from official websites of Federal Inland Revenue Services (FIRS), UNCTAD, FDI/MNE database, World Bank Report, United Nations Development Programme (UNDP) reports, CBN statistical bulletin, journals, textbooks and other relevant private and government publications. The period covered by the study stretched from 2000 to 2017. 

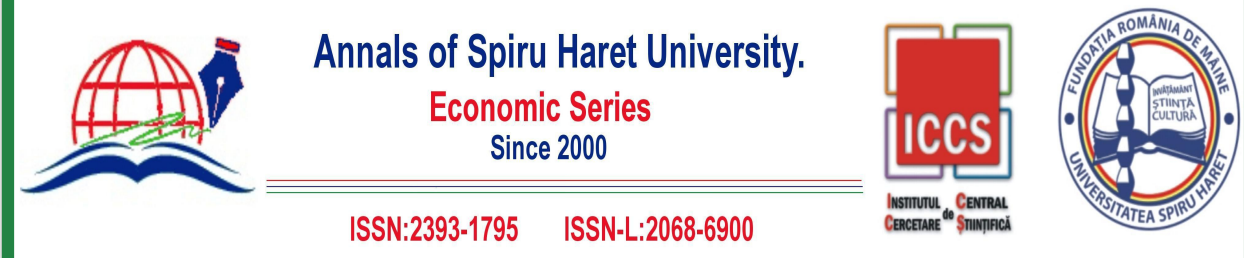

Issue 3/2019

\subsection{Techniques of Data Analysis}

Ordinary Least Squares (OLS) regression technique was used in analyzing data gathered having established the relationship between dependent and independent variables. Economic approach was used in estimating the relationship between taxation and economic growth. This regression technique has been employed in previous studies such as Ihenyen and Mieseigha (2014), Balestra (1970); Okafor (2012) and was found suitable owing to its distinctive properties of linearity, efficiency, sufficiency, least variances, unbiasedness and least mean errors.

\subsection{Model Specification}

The functional relationship between tax revenue and the economic growth of Nigeria is expressed as shown below:

$\mathrm{GDP}=\mathrm{F}(\mathrm{FDI}, \mathrm{TR})$

Obtaining the OLS model from the above expression thus:

$$
\mathrm{GDP}=\alpha+\beta 1 \mathrm{FDI}+\beta 2 \mathrm{TR}+€
$$

Where:

$$
\begin{aligned}
& \text { GDP }=\text { Gross Domestic Product } \\
& \text { FDI }=\text { Foreign Direct Investment } \\
& \text { TR }=\text { Tax Revenue } \\
& €=\text { Error term }
\end{aligned}
$$

Increased Tax Revenue and Foreign Direct Investment (FDI) are expected to increase Gross Domestic Product and so mathematically, GDP $\div$ TR $\div$ FDI.

This study places emphasis on the impact of the aggregate tax revenue on the economic growth of Nigeria and the relationship between economic growth and Foreign Direct Investment. GDP is adopted as proxy for economic growth in this study.

Table 1 shows the actual revenue collected, the Gross Domestic Product (GDP) and the Foreign Direct Investment (FDI), all in local currency unit for the periods under study, that is, 2000-2017. GDP and FDI figures are converted to Naira equivalent using Central Bank of Nigeria official exchange rate/value. 


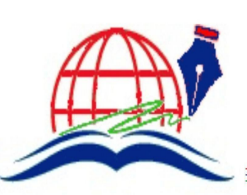

Annals of Spiru Haret University.

Economic Series

Since 2000

ISSN:2393-1795 ISSN-L:2068-6900
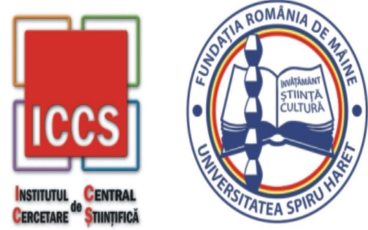

Issue 3/2019

Table 1. Tax Revenue (TR), Gross Domestic Product (GDP) and Foreign Direct Investment (FDI) of Nigeria (2000-2017)

\begin{tabular}{|l|l|l|l|}
\hline \multicolumn{1}{|c|}{ YEARS } & \multicolumn{1}{|c|}{$\begin{array}{c}\text { TR } \\
\text { ACTUAL } \\
\text { (Billions) } \\
\text { N }\end{array}$} & $\begin{array}{c}\text { GDP } \\
\text { (Trillions \& Billions of } \\
\text { Naira) } \mathbf{~} \mathbf{0 0 0}\end{array}$ & $\begin{array}{c}\text { FDI } \\
\text { (Billions \&Millions) } \\
\text { N }\end{array}$ \\
\hline $\mathbf{2 0 0 0}$ & 455.3 & $14,238,186,147.48$ & $402,012.42$ \\
\hline $\mathbf{2 0 0 1}$ & 586.6 & $13,548,157,335.53$ & $392,097.93$ \\
\hline $\mathbf{2 0 0 2}$ & 433.9 & $18,145,916,438.84$ & $626,239.39$ \\
\hline $\mathbf{2 0 0 3}$ & 703.1 & $20,766,952,085.84$ & $666,511.23$ \\
\hline $\mathbf{2 0 0 4}$ & $1,194.80$ & $26,964,151,823.86$ & $652,913.35$ \\
\hline $\mathbf{2 0 0 5}$ & $1,741.80$ & $34,454,631,985.55$ & $1,528,089.19$ \\
\hline $\mathbf{2 0 0 6}$ & 1866.20 & $44,639,666,324.15$ & $1,503,379.71$ \\
\hline $\mathbf{2 0 0 7}$ & 1846.90 & $51,092,199,951.78$ & $1,868,312.57$ \\
\hline $\mathbf{2 0 0 8}$ & $2,072.20$ & $63,865,476,168.63$ & $2,531,907.77$ \\
\hline $\mathbf{2 0 0 9}$ & $2,107.60$ & $52,022,290,419.03$ & $2,655,086.81$ \\
\hline $\mathbf{2 0 1 0}$ & $2,839.30$ & $113,283,723,499.89$ & $1,872,088.05$ \\
\hline $\mathbf{2 0 1 1}$ & $4,628.50$ & $126,384,759,935.38$ & $2,736,428.56$ \\
\hline $\mathbf{2 0 1 2}$ & 5007.70 & $141,489,780,096.61$ & $2,187,755.43$ \\
\hline $\mathbf{2 0 1 3}$ & $4,805.6$ & $158,068,901,858.04$ & $1,721,529.08$ \\
\hline $\mathbf{2 0 1 4}$ & $4,714.6$ & $174,500,748,892.61$ & $1,440,761.91$ \\
\hline $\mathbf{2 0 1 5}$ & $3,741.8$ & $147,663,255,629.28$ & $940,556.19$ \\
\hline $\mathbf{2 0 1 6}$ & $3,307.5$ & $123,803,499,734.45$ & $1,365,528.47$ \\
\hline $\mathbf{2 0 1 7}$ & $4,027.94$ & $115,342,820,583.35$ & $1,075,245.85$ \\
\hline TOTAL & $\mathbf{4 6 , 0 8 1 . 3 4}$ & $\mathbf{1 , 4 4 0 , 2 7 5 , 1 1 8 , 9 1 0 . 9 1}$ & $\mathbf{2 6 , 1 6 6 , 4 4 3 . 9 1}$ \\
\hline & & & \\
\hline
\end{tabular}

Source: UNCTAD, FDI/MNE database (www.unctad.org/fdistatistics) and FIRS. 


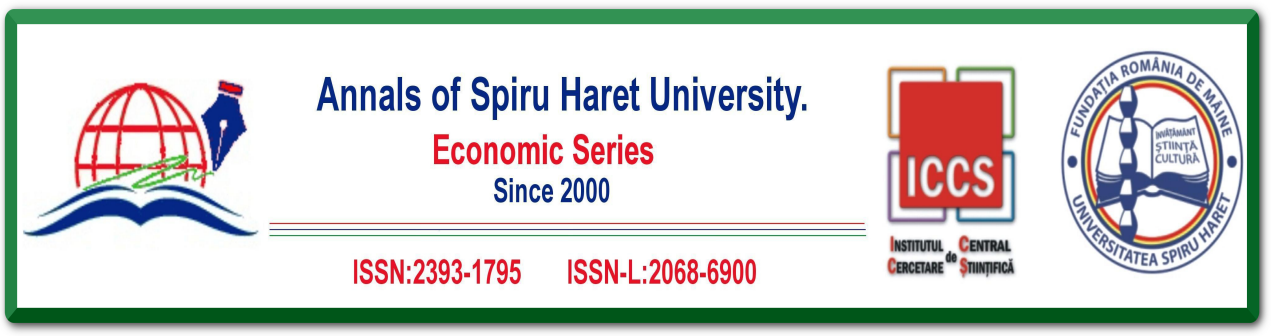

Issue 3/2019

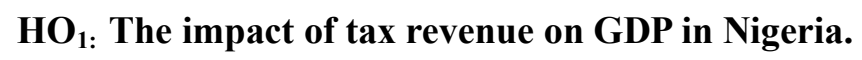

Table 2. Tax Revenue (TR) and Gross Domestic Product (GDP), 2000-2017

\begin{tabular}{|l|l|l|}
\hline \multicolumn{1}{|c|}{ YEARS } & \multicolumn{1}{|c|}{$\begin{array}{c}\text { TR:ACTUAL (BILLIONS IN } \\
\text { NAIRA) }\end{array}$} & $\begin{array}{c}\text { GDP } \\
\text { (Trillions \& Billions of Naira) } \\
\text { N'000 }\end{array}$ \\
\hline 2000 & 455.3 & $14,238,186,147.48$ \\
\hline 2001 & 586.6 & $13,548,157,335.53$ \\
\hline 2002 & 433.9 & $18,145,916,438.84$ \\
\hline 2003 & 703.1 & $20,766,952,085.84$ \\
\hline 2004 & $1,194.80$ & $26,964,151,823.86$ \\
\hline 2005 & $1,741.80$ & $34,454,631,985.55$ \\
\hline 2006 & 1866.2 & $44,639,666,324.15$ \\
\hline 2007 & 1846.9 & $51,092,199,951.78$ \\
\hline 2008 & $2,072.20$ & $63,865,476,168.63$ \\
\hline 2009 & $2,107.60$ & $52,022,290,419.03$ \\
\hline 2010 & $2,839.30$ & $113,283,723,499.89$ \\
\hline 2011 & $4,628.50$ & $126,384,759,935.38$ \\
\hline 2012 & 5007.7 & $141,489,780,096.61$ \\
\hline 2013 & $4,805.60$ & $158,068,901,858.04$ \\
\hline 2014 & $4,714.60$ & $174,500,748,892.61$ \\
\hline 2015 & $3,741.80$ & $147,663,255,629.28$ \\
\hline 2016 & $3,307.50$ & $123,803,499,734.45$ \\
\hline 2017 & $4,027.94$ & $115,342,820,583.35$ \\
\hline TOTAL & $\mathbf{4 6 , 0 8 1 . 3 4}$ & $\mathbf{1 , 4 4 0 , 2 7 5 , 1 1 8 , 9 1 0 . 9 1}$ \\
\hline
\end{tabular}




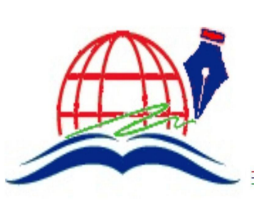

Annals of Spiru Haret University.

Economic Series

Since 2000
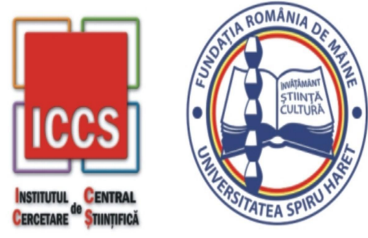

Issue 3/2019

\section{Testing of Hypotheses}

HO$_{1:}$ Aggregate Tax revenue has no significant impact on GDP in Nigeria.

Regression analysis on the impact of aggregate tax revenue economic growth

\begin{tabular}{|c|c|c|c|c|c|c|}
\hline \multirow{2}{*}{\multicolumn{2}{|c|}{ Model }} & \multicolumn{2}{|c|}{ Unstandardized Coefficient } & \multirow{2}{*}{$\begin{array}{l}\text { Standardized } \\
\text { Coefficients }\end{array}$} & \multirow[b]{2}{*}{$\mathrm{t}$-cal value } & \multirow[b]{2}{*}{ Sig. } \\
\hline & & $\mathrm{B}$ & Std. Error & & & \\
\hline \multirow[t]{3}{*}{1} & (Constant) & 0.218 & 0.127 & & 1.224 & 0.009 \\
\hline & $\mathrm{TR}$ & 0.789 & 0.061 & 0.752 & 8.789 & 0.001 \\
\hline & $\mathrm{R}^{2}$ & 0.867 & & & & \\
\hline
\end{tabular}

The size of the coefficient of the independent variable $(\beta 1)$ shows that a $1 \%$ increase in TR will cause a $0.79 \%$ increase in GDP. Also, the R-squared showed that about $87 \%$ variations in GDP can be attributed to TR, while the remaining $23 \%$ variations in GDP are caused by other factors not included in this model. This shows a strong explanatory power of the model. This is further emphasized by the T-statistic p-value of 0.001 , which shows that the regression result is statistically significant because it is less than $5 \%$, level of significance adopted for this study. Therefore, the model is adequate and the null hypothesis two that states that the tax revenue has no significant impact in the economic growth of Nigeria is rejected. Therefore, tax revenue has a significant impact on GDP in Nigeria.

$\mathrm{HO}_{2}$ : The relationship between tax revenue and FDI in Nigeria. 


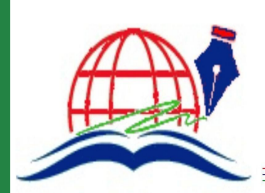

Annals of Spiru Haret University.

Economic Series

Since 2000

ISSN:2393-1795 ISSN-L:2068-6900
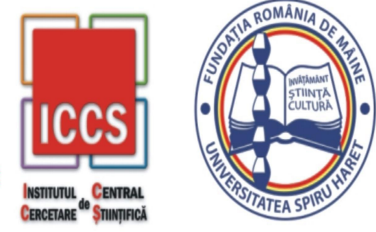

Issue 3/2019

Table 3. Tax Revenue (TR) and Foreign Direct Investment (FDI) in Nigeria (20002017)

\begin{tabular}{|c|c|c|}
\hline YEARS & $\begin{array}{c}\text { TR:ACTUAL (BILLIONS IN } \\
\text { NAIRA) }\end{array}$ & $\begin{array}{c}\text { FDI } \\
\text { (Billions \&Millions) } \\
\mathbf{N}\end{array}$ \\
\hline 2000 & 455.3 & $402,012.42$ \\
\hline 2001 & 586.6 & $392,097.93$ \\
\hline 2002 & 433.9 & $626,239.39$ \\
\hline 2003 & 703.1 & $666,511.23$ \\
\hline 2004 & $1,194.80$ & $652,913.35$ \\
\hline 2005 & $1,741.80$ & $1,528,089.19$ \\
\hline 2006 & 1866.2 & $1,503,379.71$ \\
\hline 2007 & 1846.9 & $1,868,312.57$ \\
\hline 2008 & $2,072.20$ & $2,531,907.77$ \\
\hline 2009 & $2,107.60$ & $2,655,086.81$ \\
\hline 2010 & $2,839.30$ & $1,872,088.05$ \\
\hline 2011 & $4,628.50$ & $2,736,428.56$ \\
\hline 2012 & 5007.7 & $2,187,755.43$ \\
\hline 2013 & $4,805.60$ & $1,721,529.08$ \\
\hline 2014 & $4,714.60$ & $1,440,761.91$ \\
\hline 2015 & $3,741.80$ & $940,556.19$ \\
\hline 2016 & $3,307.50$ & $1,365,528.47$ \\
\hline 2017 & $4,027.94$ & $1,075,245.85$ \\
\hline TOTAL & $46,081.34$ & $26,166,443.91$ \\
\hline
\end{tabular}

$\mathrm{HO}_{2}$ : There is no positive relationship between aggregate tax revenue and FDI on Nigerian economic development. 


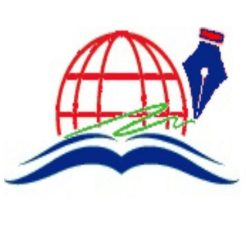

Annals of Spiru Haret University.

Economic Series

Since 2000
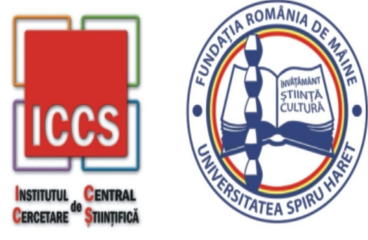

Issue 3/2019

Regression analysis of foreign direct investment and tax revenue on Gross Domestic Product

\begin{tabular}{|c|c|c|c|c|c|c|}
\hline \multirow[b]{2}{*}{ Model } & & \multicolumn{2}{|c|}{$\begin{array}{l}\text { Unstandardized } \\
\text { Coefficients } \\
\end{array}$} & \multirow{2}{*}{$\begin{array}{l}\text { Standardized } \\
\text { Coefficients } \\
\text { Beta }\end{array}$} & \multirow[b]{2}{*}{$\mathrm{t}$-cal value } & \multirow[b]{2}{*}{ Sig. } \\
\hline & & B & Std. Error & & & \\
\hline \multirow[t]{2}{*}{1} & (Constant) & 0.207 & 0.161 & & 1.286 & 0.003 \\
\hline & FDI & 0.810 & 0.051 & 0.875 & 8.667 & 0.000 \\
\hline \multirow[t]{2}{*}{2} & $\mathrm{TR}$ & 0.883 & 0.027 & 1.033 & 6.778 & 0.001 \\
\hline & $\mathrm{R}^{2}$ & 0.688 & & & & \\
\hline
\end{tabular}

The result above reveals a significant positive relationship between each of the surrogates of Foreign Direct Investment and Tax Revenue collected on Gross Domestic Product measured by Log (GDP) for the period under study. With a p- value of +0.000 , $+0.001<0.05 \%$ significance level, this shows that strong positive relationships exist between FDI and TR on GDP. Therefore there is a positive relationship between tax revenue and FDI in Nigeria. It implies also that on the aggregate, the foreign direct investment and tax revenue collected by the Federal Government of Nigeria has a positive relationship on Economic Growth of the country.

\subsection{Results and Discussion}

The study examined the impact of tax revenue on economic growth of Nigeria. It further investigated the relationship between foreign direct investment (FDI) and economic growth in Nigeria. From the findings of the study, the regression analysis adopted to test hypothesis one showed that tax revenue has a significant impact on GDP in Nigeria and with p-value of $0.001 \%<0.05 \%$ significance level. The regression result further revealed that there is a positive relationship between tax revenue and FDI in Nigeria, with a p-value of $+0.000,+0.001<0.05 \%$ significance level. This implies that a unit increase in foreign direct investment (FDI) and tax revenue (TR) leads to a 1\% increase in Nigerian GDP. This is in consonance with the findings of Bukie and Adejumo (2013) as quoted in Ofoegbu, Akwu and Oliver 52 


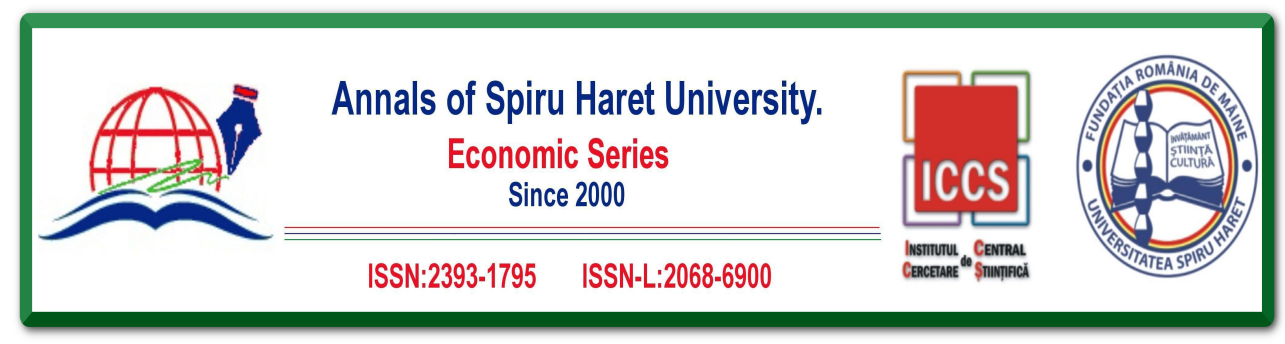

Issue 3/2019

(2016), which discovered that the tax revenue and economic growth have a positive and significant relationship. Furthermore, Worlu and Emeka (2012) in a similar study found out that tax revenue has both direct and indirect correlation with the infrastructural development and the gross domestic product respectively (GDP).

\section{Findings and Conclusion}

The study reveals that tax revenue has significant impact on GDP in Nigeria. This implies that the more tax revenue increases, the more proportionately the GDP increases resulting in economic growth of Nigeria. It shows that there is positive relationship between foreign direct investment and Gross Domestic Product; therefore the more FDI increases, the more the economy grows. That is to say that economic growth is directly related to foreign direct investment. The study recommended a functional tax structure that would ensure that tax is collected from all taxable individuals, group of individuals and corporate bodies and remitted accordingly to the government without diversion and should be instituted to widen the revenue base of the country. Government should equally concentrate on providing critical infrastructure to support indigenous investors and foreign investors that are ready to invest in the economy. The economy should be liberalized by the government through the removal of all barriers to trade such as arbitrary tariffs, import and export duties and other levies to encourage foreign investors.

\section{References}

[1] Adegbie, F.F. \& Fakile, A.S. (2011). "Company income tax and Nigeria economic development." European Journal of Social Sciences, 22(2), 309-332.

[2] Adereti, S.A., Adesina, J.A. \& Sanni, M.R. (2011). "Value added tax and economic growth of Nigeria." European Journal of Humanities and Social Sciences, 10(1), 555-571.

[3] Anyaduba, J.O. (2004). "Partnership taxation in Nigeria." ICAN Student Journal, 9(2), 15-17.

[4] Anyaehie, C.M. \& Areji, C.A. (2015). "Economic diversification for sustainable development in Nigeria." Open Journal of Political Science, 5, 87-94.

[5] Apata, T.G., Folayan, A., Apata, O.M. \& Akintua, J. (2011). The economic role of Nigeria's subsistence agriculture in the transition process: Implications for rural development. Paper Presented at the 85th Annual Conference of the Agricultural Economics Society, 18-20th April, Warwick University, Warwick. 

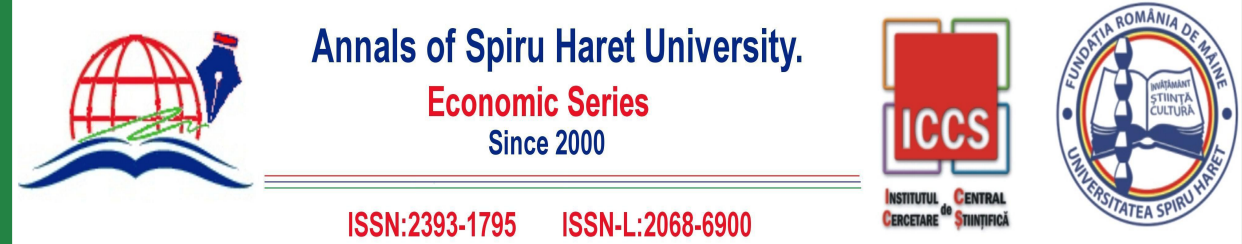

\section{Issue 3/2019}

[6] Baghebo, M. (2012). "Effective utilization of tax revenue in Nigeria." International Journal of Academic Research in Business and Social Sciences, 7(2), 280-289.

[7] Balestra, P. (1970). On the efficiency of ordinary least-squares in regression models. Journal of the American Statistical Association, 65(331), 1330- 1337.

[8] Bird, M.R. \& Zolt, M.E. (2003). Introduction to tax policy design and development. Available from http://www.worldbank.org/ [Accessed 1st October, 2015].

[9] Brautigam, D. (2008). Taxation and governance in Africa. AEI online. Available from $\mathrm{http} / / / \mathrm{www}$.aei.org/publication/taxation-and-governance-in-africa [Accessed 27th September, 2015].

[10] Bukie, H.O. \& Adejumo, T. (2013). "The effect of tax revenue on economic growth in Nigeria." International Journal of Humanities and Social Invention, 2(6), 16-26.

[11] Bukie, O.H., Adejumo, O.T. \& Edame, G.E. (2013). "The effects of tax revenue on economic growth of Nigeria." International Journal of Humanities and Social Science, 2(6), 16-26.

[12] Ezejelue, A.C. \& Ihendinihu, J.U. Personal Income Taxation in Nigeria. LIins Consult Nig, Okigwe, 2006.

[13] Ezirim, A.C., Okeke, C.T. \& Ebiringa, O.T. (2010). "Achieving vision 2020 in Nigeria: A review of the economic and karket-oriented business reforms." Journal of Sustainable Development in Africa, 12(4), 58-71.

[14] Federal Inland Revenue Service (2014). Annual summary of collected tax in Nigeria. Available online at: www.firs.gov.ng.

[15] Global Alliance for Tax Justice (2015). Position Paper and Recommendations for the Third UN Conference on Financing for Development.

[16] Ihenyen, C.J. and Mieseigha, E.G. (2014). "Taxation as an instrument of economic growth (The Nigerian Perspective)." Information and Knowledge Management, 4(12), 49-53.

[17] Kiabel, B.D. and Nwokah, N.G. (2009). "Boosting revenue generation by state governments in Nigeria: The tax consultants' option revisited." European Journal of Social Sciences, 8(4), 532-539.

[18] Koutsoyiannis, A. Theory of econometrics. London: The Macmillan Press Ltd, 1977.

[19] Kusi, N.K. (1998). "Tax reform and revenue productivity in Chana. Nairobi, Kenya: The African Economic Research Consortium." International Journal of Asian Social Science, 6(10), 604-613.

[20] Ogbonna, G. N. (2012). "Impact of tax reforms and economic growth of Nigeria: A time series analysis." Current Research Journal of Social Sciences, 4 (1), 62-68.

[21] Omodero, C.O. (2019). "A relative assessment of the contributions of agriculture, oil and Non-oil tax revenues to Nigeria's economic expansion." Annals of Spiru Haret University, Economic Series, 19(2), 139-151. 